\title{
Introduction: Alternative Dickens, Dickensian Alternatives
}

\section{Christopher Pittard, University of Portsmouth}

Why Alternative Dickens? This collection originally arose out of ways of thinking about Dickens explored in the bicentenary conference I co-organised at the University of Portsmouth, The Other Dickens (2012), in which we invited papers that considered 'others' within Dickens, other approaches to Dickens, and other aspects of his life and work that had not received prominent critical attention, across both Victorian and NeoVictorian contexts. However, there was also a sense in which Dickens had already been comprehensively 'othered' since the millennium, most notably in John Bowen's Other Dickens (2000), but also in Lillian Nayder's The Other Dickens: A Life of Catherine Hogarth (2011), which partially inspired the Portsmouth conference. 'Other', it seems, has become overly capacious, or runs the risk of becoming familiar; 'alternative,' by contrast, reframes questions of otherness. 'Alternative' seems culturally and politically self-divided in a way that the more psychoanalytically valenced 'other' is not. On one hand, alternative politics and alternative comedy suggest radical (in the political sense) resistance; on the other, the last few years have seen the emergence of 'alternative facts' and, of course, the alt-right. This tension means that 'alternative' carries within itself the potential of its collapse; as Mark Fisher notes in Capitalist Realism: Is There No Alternative? (2009), the self-consciously alternative can all too easily be co-opted into dominant ideologies. "“Alternative' and 'independent' don't designate something outside mainstream culture," Fisher notes, "rather, they are styles, in fact the dominant styles, within the mainstream" (9). The aim of these articles is not so much to place Dickens at one end of the alternative spectrum or the other (as if Dickens turned out to be either Alexei Sayle or Sean Spicer), but to explore moments of the alternative in his work: 
where his novels deal with competing outcomes, storylines, and where Dickens himself negotiates a literary marketplace of alternatives to himself, persuading readers that he is a viable alternative to, say, Reynolds. Imbricated with these approaches is the idea of counterfactuality (so-called alternative history), an increasingly relevant cultural tool. Counterfactuality has currency: Philip Roth's The Plot Against America (2004) re-entered the bestseller lists in late 2016 following the election of Donald Trump, while closer to Dickens studies, Robert Douglas-Fairhurst's Becoming Dickens: The Invention of a Novelist (2011) begins with a vision of an alternative 1855 inspired by William Gibson and Bruce Sterling's The Difference Engine (1990). Douglas-Fairhurst notes that Dickens is a conspicuous absence from Gibson and Sterling's novel, invoking another of Dickens' interests when he says that "The absence of Dickens is surprising. No Victorian writer is harder to make vanish through a counterfactual conjuring trick" (3).

Alternatives - or their lack - were in the news not long after The Other Dickens. In March 2013, then Prime Minister David Cameron justified his austerity politics with recourse to the claim that "There is no alternative" (Parker, n.p). The echo of Margaret Thatcher's use of the phrase, and her famed espousal of 'Victorian values' (for which, read an ideologically rather than historically constructed model of Victorianism), was deliberate. As Fisher argues, "there is no alternative" is "as succinct a slogan of capitalist realism as you could wish for" (8). Yet the phrase has a genealogy that extends further back than late capitalism. The pscittine Cameron may have been quoting Thatcher, but Thatcher in turn drew on a rhetorical inheritance from Herbert Spencer, whose Social Statics (1851) obsessively uses "There is no alternative" and its variants to argue for a classical economic liberalism. We might start, therefore, by considering the Victorian, and more specifically Dickensian, deployment of 'there is no alternative.' 
Unlike the Thatcherian usage Spencer uses the phrase to reflect not only on the content of a philosophical position, but also on the manner in which that position is to be logically presented (as in, for instance, on the derivation of a first principle of liberty): There is clearly no alternative but to declare man's freedom to exercise his faculties; for without this freedom fulfilment of the Divine will is impossible. There is clearly no alternative but to declare the several limitations of that freedom needful for the achievement of greatest happiness. And there is clearly no alternative but to develop the first and chief of these limitations separately; seeing as we have done that a development of the others is at present impossible (88).

Spencer's style, self-consciously blocking off potential channels of thought in order to construct an argument that in retrospect appears logically necessary, is the antithesis of Dickensian style, which plays with potentialities. Great Expectations provides perhaps the most famous statement of Dickens' tarrying with the alternative:

That was a memorable day to me, for it made great changes in me. But, it is the same with any life. Imagine one selected day struck out of it, and think how different its course would have been. Pause you who read this, and think for a moment of the long chain of iron or gold, of thorns or flowers, that would never have bound you, but the formation of the first link on one memorable day. (72)

The passage is remarkable for the way in which potentiality arises out of homogeneity ("it is the same with any life"), a shift reflected in the paradoxical status of 'struck', which at first appears as a figure of deletion ("struck out") but with the introduction of the chain imagery (imported, of course, from elsewhere in the novel) recalls striking as an act of forging, of creation. 'Struck' here acts in similar manner to Gerard Manley Hopkins' 'buckle' in "The 
Windhover" (1877; published 1917) (another image of metalwork, incidentally), where the diametrically opposed meanings of breaking and binding co-exist without one having priority over the other; Dickens' passage enacts the shift in interpretation it asks its readers to consider in their own personal histories.

Dickens deploys the Spencerian phrasing occasionally, but does so in order to undermine it; when Dickens' characters claim they have 'no alternative,' they frequently refer either to bathetically inconsequential conflicts, or events that never happen despite claims of inevitability, in stark contrast to Spencer's usage of the term to indicate logical or political necessity. Anticipating Spencer, the phrase and its variants appear most frequently in The Pickwick Papers. On their journey to Bath, Pickwick encounters a "fierce gentleman" called Mr Dowler, who recounts the story of winning his present wife from a rival suitor: "I said I had pledged my word as a gentleman to skin him. My character was at stake. I had no alternative. As an officer in His Majesty's service, I was bound to skin him. I regretted the necessity, but it must be done. He was open to conviction. He saw that the rules of the service were imperative. He fled. I married her." (581)

Dowler may be a comedically angry character, but the specificity of his threats of skinning a rival are clearly overblown and never actually come to pass. The phrase of having 'no alternative' becomes associated with Dowler, when later in the novel Dowler backs off from the threat of a duel with Winkle:

As the real state of the case dawned upon Mr Winkle's mind, he looked very terrible, and said he was perfectly satisfied; but at the same time, said so, with an air that left Mr Dowler no alternative but to infer that if he had not been, something most horrible and destructive must inevitably have occurred. (631) 
Readers, on the other hand, know that Dowler is too quick to foreclose the alternative of reading the situation correctly; that, in fact, that the proposed duel is an entirely fictional possibility. On the bathetic use of 'no alternative', in Bath the Pickwickians witness the resignation of the footman Whiffers, who when pressed for an explanation "had no alternative but to state, boldly and distinctly, that he had been required to eat cold meat" (615). The only genuine 'no alternative' in The Pickwick Papers refers, again bathetically, to the laws of physics, when Ben Allen comedically attempts to strangle the surly Mr Martin, after hearing that Arabella has married Winkle. Martin "felled Mr Benjamin to the ground. As that gentleman had his hands entangled in his cravat, he had no alternative but to follow him to the floor" (767).

A more subtle undermining of the phrase (this time deployed in precisely Spencerian arrangement) occurs at the other end of Dickens' career. In The Mystery of Edwin Drood, when the Dean insists that the suspected Neville Landless should leave the shelter of Crisparkle's house (lest giving sanctuary to an assumed murderer should tarnish the church), he caps the argument with "There is no alternative, as your good sense has discovered" (185). The irony here is that Crisparkle's 'discovery' is really the Dean's projection of his own assurance ("“And if it be a necessity-" Crisparkle faltered. "As you unfortunately find it to be," returned the Dean' (185)). Yet Dickens tends to use 'alternative' somewhat sparingly; after the atypical The Pickwick Papers, the term usually appears once or twice per novel. Strikingly, in the three novels most structurally and thematically concerned with alternatives - the competing timelines of A Christmas Carol, the dual narration of Bleak House, and the double visions of A Tale of Two Cities - the word is entirely absent.

This is not, however, to say that the subjunctive does not appear at the linguistic level in Dickens' work, but rather only to historicise 'alternative' as a more modern framing of narrative potential. Where we might say 'alternative', Dickens preferred 'as if,' a rhetorical 
figure which has attracted increased critical attention in the last ten or so years. Julian Wolfreys notes that 'as if' partially derives from the Kantian als $o b$ (as though, as if), and "installs in writing the possibility of imaging a relation between experience or fact and a fictionalized experience.... The as if names a 'fictional' condition, an imagined and therefore phantasmatic possibility that is not a lie, but which either has not happened, or which, more significantly, cannot be experienced as such.... As if institutes a hinge if you will between the possible and the impossible. It names the spectral condition of imagination as the projection of fiction and narratives" (12). Likewise, John Reed draws on an Iserian model of "the imaginary' as proposing that "underlying all human intellectual activity is our power to conceive, in an 'as if' manner, what does not yet exist" (Reed 22). Philip Davis considers the rhetorical strategy of 'as if' in William James' The Varieties of Religious Experience, arguing that the trope frames "ideas that seem to create a vitality in us and make for greater possible movement into a future.... [T] hey are instrumental and provisional, essays in the very process of our making ourselves do more and be more and go further than we might dare in advance" (46). The Kantian 'as if' encompasses alternatives in the present (the fictional condition), whereas James' has a more temporal (and self-actualising) dimension; that which is to come. There is a sense in which all fiction already fulfils the condition of the as if - that which has not actually happened, but is not exactly a lie - but this does not get us very far. Rather, there is something in the 'as if' which also calls attention to itself as the possibility of an alternative; that we are reading this particular fiction, and not another. This somewhat excessive figure of the 'as if' underwrites Reed's argument that Dickens subverts the expectations of realism through the depiction of a reality at once heightened and subjunctive. Reed refers to this mode as 'hyperrealism,' but the phrase most frequently tied to 'as if' in recent critical discourse, as if to connect historicist rhetoric to the language of technology, is 'virtual reality'; see, for instance, Michael Saler's As If: Modern Enchantment and the 
Literary Prehistory of Virtual Reality (2012) and Jonathan Farina's influential article for Victorian Studies, “'Dickens’s As If”: Analogy and Victorian Virtual Reality’ (2011).

This latter discussion is of particular relevance to Alternative Dickens. Farina helpfully tabulates the occurrence of the 'as if' figure in Dickens' works: " 411 in Dombey and Son (1846-48), 393 in David Copperfield (1849-50), 392 in Our Mutual Friend, 266 in the substantially shorter Great Expectations (1860-61)"; 311 in Bleak House (Farina 427, 429). For Farina, "As if underwrites the way Victorians could know, and this epistemology suggests they could only know reality to the degree that they could know each other. Recurrent 'as ifs' present the narrative in which they occur as a conjectural history of some real story that purportedly precedes, exceeds, or otherwise eludes its narrator's perspective" (432). The crucial point here is the connection Farina makes between subjunctive epistemology and character, noting how Dickens' deployment of 'as if' marks moral and emotional complexity in character (in, for instance, Esther's narration in Bleak House); the use of "conditional simile characterizes Victorian feeling as virtual experience irreducible to words" (430). In other words, it is those characters who are the most keenly aware of the inadequacies of describing feeling and experience that have recourse to conditional analogy and the subjunctive. This depth of character becomes associated with moral depth; noting the centrality of analogy and 'as if' to John Tyndall's Fragments of Science (1892), Farina argues that for Tyndall, the moral dimension of 'as if' emerges: that which "epitomizes a moral imperative and self-abnegating principle inherent in the proper scientist" (Farina 434). 'As if' implies a proper doubt and scepticism that distinguishes knowledge from dogmatism: “"As if” bespeaks both the depth of subjects of scientific inquiry and the moral depth of those who study it properly" (434). The conditions by which we know the world are also those by which we know others, and both are reliant on the 'as if' of analogy. Farina is careful here to dissociate his use of 'virtual reality' from its modern technological sense; rather, Dickens' 'as 
ifs" "conceptualize reality itself as virtual, as the abstract depth of a character" (433). To return to alternatives, Farina's 'as if' provides the counterweight to my 'no alternative,' both in the sense that the Dickensian “"As if” imagines access to foreclosed perspectives" (429), and that the use of 'no alternative' in Dickens indicates shallowness of moral character, from the blustering cowardice of Dowler to the rhetorical trickery of the Dean of Cloisterham.

While in these introductory comments I have focused on a particular manifestation of the subjunctive and the alternative, the following articles that comprise Alternative Dickens take a broader view. They explore a range of Dickensian alternatives, from the inscription of alternatives within the texts (through gestures of doubling and recycling) to alternatives to Dickens in the form of plagiarists, copyists, and implied different endings. The article closest to the linguistic subjunctive is Camilla Uelland Hoel's "Secret Plots: The False Endings of Dickens' Novels", which considers the deployment of narrative alternatives within the novels themselves. Hoel takes as her theoretical starting point Susan K. Gilman and Robert L. Patten's discussion of the 'ontogenetic' qualities of Dickens' work, in which narrators imagine a wide variety of possible futures for characters (most notably Esther's speculations on alternative outcomes while travelling with Bucket in Bleak House). Hoel notes that Gillman and Patten's suggestive discussion of alternatives largely restricts itself to analysis of character; Hoel moves the discussion to that of plot, arguing that Dickens' plots spectrally imply alternatives (most literally, of course, in A Christmas Carol), with the resolutions of the novels providing what Hoel describes as 'false endings' that, through the disjuncture between narrative closure and the socio-political questions raised through the texts, imply that some other ending is possible. Through readings of the problematic conclusions of Oliver Twist, Little Dorrit, and Our Mutual Friend, Hoel demonstrates how Dickensian resolutions draw attention to their very fictionality, and thus trigger resistant readings, and the imagination of alternative endings. Hoel traces the growing sophistication with which 
Dickens' resolutions hint at alternative narratives just below the surface; in his early career, narrative problems are resolved through too neat a concatenation of coincidence that leave political questions untouched (Oliver Twist); later novel endings feature ostentatiously complex chains of relation and inheritance that Dickens himself required mnemonic assistance to navigate (Hoel quotes Hilary Schor's observation that recent editors of Little Dorrit have found it necessary to include a summary of the complex network of wills that resolve the novel, and still get the details wrong). This movement culminates in Our Mutual Friend's challenge to the reader to construct their own narratives (that is, to become of that text's many storytellers), though Hoel argues that Dickens ultimately moves away from a narrowly defined ontogenetic mode towards a more doubled sense of narrative that keeps alternatives in play.

Michelle Wilson’s “Buried Narratives, Secret Plots: Exhuming the Mother's Story in Oliver Twist" starts strikingly with reflections on a different kind of alternative; the ways in which literary texts subvert our critical expectations, moving projects into different lines of enquiry. Wilson finds that Twist initially refused to fit into her initial project, leading to a reconceptualization of her account of mothers, father, and inheritance. Noting that the novel immediately kills off Oliver's mother, and seems to be successful in keeping her dead, Wilson notes that Oliver Twist poses another question: what happens when the mother dies in the wrong place? Oliver himself becomes the trace - both the clue and the pathway - to unravelling this problem. In Wilson's reading, the dead mother's story is supplanted by the paternal inheritance plot, even though the narrative interest keeps moving back towards the absent mother (and, as Wilson argues, while paternity is the force which makes meaning out of the novel's complex inheritance plot, paternity must first be proved through the establishment of maternity). Oliver, insisting on the dead status of his mother (not least to Noah Claypole), finds this parental role instead filled by a variety of competing characters 
(Fagin, Nancy, and Sally) two laws: the Poor Law, and the laws of narrative. Death and storytelling become the intertwined narratives of Oliver Twist; Wilson concludes that the women of the novel - including Agnes - are 'reverse Scheherazdes', for whom death is the price of having a story to tell.

Two articles consider alternatives to Dickens through the prism of literary competition. Ruth Doherty's “Blest or t'othered: Alternative Graveyards in Bleak House, Reynolds, and Walker", considers the notoriously antagonistic literary relationship of Dickens and G. W. M. Reynolds, offering historicised readings of the graveyard spaces of Bleak House and The Mysteries of London. Doherty positions these texts as alternatives to each other, exploring the same sets of symbols but with reference to different implied readerships and literary styles. For Doherty, Dickens' style relies for its effect on the alternatives provided by the reader's imagination; Reynolds, by contrast, attempts to provide a more comprehensive, visceral description of bodily decay. Plagiarism enters the equation via Reynolds' verbatim redeployments of contemporary medical accounts of graveyards, most notably the doctor and sanitary reformer George Alfred Walker. Walker becomes the triangulating figure between Dickens and Reynolds; both were aware of the reformer's writings, but engaged with them in fundamentally different ways. Doherty uses these contexts to articulate a new reading of Krook's spontaneous combustion, moving beyond contemporary associations of Krook's death with alcoholism, and more recent critical accounts that reduce spontaneous combustion to a metaphorical image of social and legal corruption. Her discussion invites us to reconsider the material world of Bleak House, hinting at a recycling economy more usually associated with Our Mutual Friend; where, exactly, does repurposed coffin wood end up? Finally, Matthew Crofts explores another kind of potential recycling, noting that the gothic doubling of A Tale of Two Cities extends beyond the boundaries of the text to the parallels between Dickens' novel and Watts Phillips' play 
The Dead Heart, a familiar sounding drama of imprisonment in the Bastille, eventual release, and heroic self-sacrifice. Watts' play was accused of plagiarising Dickens' novel, a claim which while not entirely refuted by Phillips' supporters, was at least questioned, not least by reviewers who saw Phillips' work as superior. As Crofts points out, the play was revived by Henry Irving in 1899 , leading to a resurrection of questions of Dickensian intellectual property some time after these issues had vexed Dickens himself (Irving himself consulted $A$ Tale of Two Cities in his restaging of The Dead Heart, leading to a dizzying circling of influence). The various claims and counter-claims of plagiarism that surround these two contemporaneous texts complicate ideas of the alternative, unsettling any easy conception of original and copy. As Mark Fisher notes in the quotation discussed at the outset of the introduction, the alternative is already the mainstream.

\section{Works Cited}

Bowen, John. Other Dickens: Pickwick to Chuzzlewit. Oxford: Oxford University Press, 2000.

Davis, Philip. Why Victorian Literature Still Matters. Chichester: Wiley-Blackwell, 2008.

Dickens, Charles. Great Expectations. London: Penguin, 1996.

----. The Mystery of Edwin Drood. London: Penguin, 2002.

---. $\quad$ The Pickwick Papers. London: Penguin, 1986.

Douglas-Fairhurst, Robert. Becoming Dickens: The Invention of a Novelist. Cambridge MA: Harvard University Press, 2011. 
Farina, Jonathan. “'Dickens's As If”: Analogy and Victorian Virtual Reality.' Victorian Studies 53.3 (2011): 427-36.

Fisher, Mark. Capitalist Realism: Is There No Alternative? Winchester: Zero, 2009.

Nayder, Lillian. The Other Dickens: A Life of Catherine Hogarth. Ithaca: Cornell University Press, 2011.

Parker, George. “There is no Alternative, says Cameron.” Financial Times 7 March 2013. < https://www.ft.com/content/3a39ea0e-8723-11e2-bde6-00144feabdc0 > Accessed 26 June 2018.

Reed, John R. Dickens's Hyperrealism. Columbus: Ohio State University Press, 2010.

Saler, Michael. As If: Modern Enchantment and the Literary Prehistory of Virtual Reality. Oxford: Oxford University Press, 2012.

Wolfreys, Julian. Derrida: A Guide for the Perplexed. London: Continuum, 2007. 